\title{
Innovációs törekvések a népegészségügyben
}

\author{
Innovation efforts in public health
}

A szakemberek és a laikusok számára is ismert tény, hogy a magyar lakosság egészsége sokkal rosszabb, mint ami elvárható lenne. Az is nyilvánvaló, hogy ennek megváltoztatásához, javításához elengedhetetlen a hazai népegészségügyi rendszer megújítása, amelynek kezdeti lépéseit már tapasztalhatjuk. A megújulás lehetséges irányairól bővebben az Egészségjelentés2015 című tanulmánykötet zárszavában olvashatnak az érdeklődők.

A megújulás egyik nélkülözhetetlen kelléke a konstruktív szakmai fórumok létrehozása és múködtetése. A nemzetközi felzárkózáshoz, a hatékony népegészségügyi beavatkozások kidolgozásához, megvalósításához mindenekelőtt szakmai vitákon, egyeztetéseken keresztül vezethet út. A tematikusan és formájában is megújult Egészségfejlesztés folyóirat ehhez kíván kommunikációs lehetőségeket biztosítani. Ezúton is bátorítjuk olvasóinkat, hogy szóljanak hozzá a folyóirat közleményeihez, kifejezetten az Agora rovatban található vitaindító írásokhoz.

A folyóirat 2016. 2. számának eredeti közleménye a nemzetközileg is újszerúnek tekinthető Egészségkommunikációs Felmérés (EKF) felnőttekre vonatkozó kutatási eredményeit mutatja be, amely hasznosnak bizonyulhat az innováció iránt érdeklődő népegészségügyi szakemberek számára.
Az „Agora” rovatban olyan, a hazai környezetben többnyire újdonságnak számító témákban fejtik ki szakértők - remélhetően szakmai vitát kiváltó - véleményüket, mint az EKF-hez kapcsolódó népegészségügyi beavatkozások, a viselkedésértés, az iskolakertek, a nemek közötti egészségkülönbségek és a vakcinációval kapcsolatos tévhitek.

Bízunk benne, hogy olvasóink az Egészségfejlesztés folyóiratban hozzászólóként vagy akár jövőbeli szerzőként aktívan közremúködnek a hazai népegészségügy innovációjában.

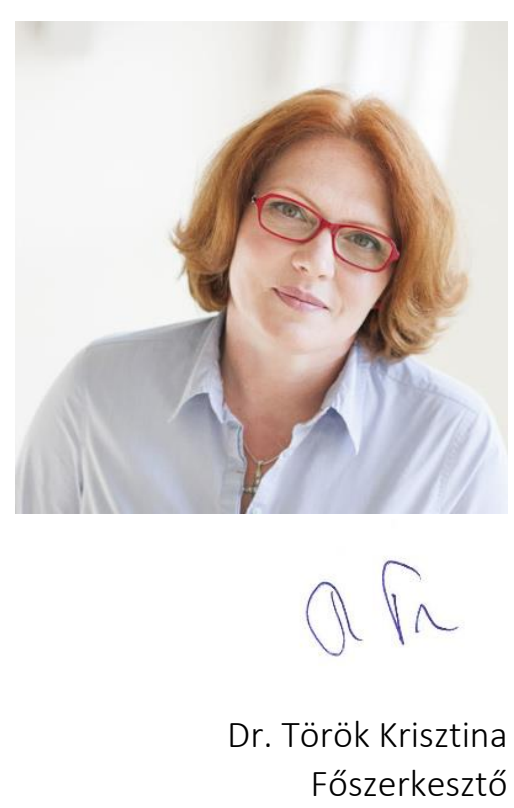

